\title{
Sistem Penyiraman Bibit Tanaman Berdasarkan Programmable Logic Controller (PLC)
}

\author{
Haryanto \\ Jurusan Teknik Informatika, Fakultas Teknik,Universitas Islam Syekh Yusuf, Jl. Mulana Yusuf No.10 Tangerang \\ Banten 15118, Indonesia \\ haryanto@unis.ac.id
}

\begin{abstract}
Abstrak.Penyiraman bibit tanaman dapat dilakukan secara otomatis dengan menggunakan teknologi Programmable Logic Controller (PLC).PLC adalah suatu sistem kontrol yang dapat diprogram dalam mengendalikan dan mengatur penyiraman bibit tanaman. Hal ini juga bisa diatur sesuai dengan kebutuhan air di setiap tahap pertumbuhan benih sampai tanaman dewasa. Dengan menggunakan sensor untuk mengukur kelembaban air dan program waktu untuk mengatur pompa air dalam mengontrol proses penyiraman sehingga benih tidak kelebihan air, sehingga pertumbuhan bibit bisa optimal.
\end{abstract}

Kata kunci:PLC, penyiraman, bibit tanaman

Abstract.[System of Plants Seed Watering Base on Programmable Logic Controller (PLC)].The watering of plants seeds could be carried out automatically by using technology development of Programmable Logic Controller (PLC). PLC is a control system that can be programmed in controlling and organizing the watering of plants seeds. It is also can be arranged according to the need of water in each step of seed growth until the plants completed mature. By using sensor to measure the water humidity and timing program to organize water pump in controlling watering process so that the seeds are not water accessed, therefore the seeds growth could be optimal.

Keywords: PLC, watering, plants seeds

\section{Pendahuluan}

Perkembangan IPTEK khususnya komputer sudah demikian majunya merambah setiap bidang kehidupan.Hampir semua aktifitas kegiatan manusia menggunakan tekhnologi modern, mulai dari dunia industri, rumah tangga bahkan bidang pertanian.Yang menjadi salah satu alasan utama banyaknya penggunaan dan pemanfaatan tekhnologi komputer adalah karena komputer mampu melakukan pekerjaan yang berulang secara terus-menerus, tanpa mengenal waktu, hal ini dapat dimanfaatkan untuk membantu manusia mengerjakan pekerjaan yang rutinitas. Pemanfaatan teknologi modern pada bidang pertanian diharapkan dapat meningkatkan hasil pertanian yang secara tidak langsung tentu akan meningkatkan kemakmuran petani dan perekonomian wilayah.

Pada budidaya tanaman, ketersedian air sangatlah penting.Bibit tanaman tidak bisa hidup dan berkembang dengan baik jika air pada tanah tidak sesuai dengan kebutuhan.Untuk itu perlu dilakukan penyiraman bibit secara teratur dan terjadwal. Ketersediaan air pada masa pembibitan tanaman harus benar-benar diperhatikan, jika kekurangan air bibit akan kering dan akhirnya mati. Sebaliknya jika kelebihan air, bibit akan busuk. Dengan selalu terpenuhinya kebutuhan akan air, maka tanaman dapat tumbuh, berbuah dan berkembang biak dengan baik. Lain halnya dengan tanaman dewasa yang sudah tumbuh, dan telah memiliki akar yang banyak dan kuat sehingga mampu mencari air dengan sendirinya, jarang disirampun biasanya dapat bertahan hidup. Saat ini penyiraman bibit masih dilakukan oleh tenaga manusia sehingga memerlukan tenaga dan waktu yang lama

Penyiraman bibit tanaman dapat dilakukan secara otomatis dengan memanfaatkan perkembangan dan kemajuan tekhnologi komputer yang sudah sangat maju, salah satunya adalah dengan memanfaatkan PLC (Programmable Logic Controller). PLC merupakan sistem pengendali yang dapat diprogram dalam mengontrol dan mengatur proses penyiraman bibit tanaman yang dapat diatur sesuai dengan kebutuhan air pada setiap tahapan pertumbuhan bibit sampai menjadi tanaman dewasa.

\section{Programmable Logic Controller (PLC)}

PLC adalah suatu peranti elektronik yang dapat dirancang agar dapat beroperasi secara digital dengan menggunakan memori sebagai media penyimpanan instruksi untuk menjalankan fungsi-fungsi logika, seperti fungsi pencacah, fungsi urutan proses, fungsi pewaktu, fungsi aritmetika, dan fungsi lain yang dapat diprogram.

Pembuatan program dapat dilakukan dengan 2 (dua) cara yaitu melalui PLC langsung dan melalui komputer. Bila program dibuat melalui komputer, 
maka perlu dipindahkan ke PLC untuk dapat dijalankan.

Perangkat lunak untuk membuat program PLC melalui komputer dapat menggunakan LOGO!soft. Dengan LOGO!soft, program dapat dibuat dan dilihat hasilnya berupa simulasi dan lebih mudah untuk diperbaiki atau untuk pengembangan. Jika sudah selesai, program dapat ditranfer ke PLC dan siap dijalankan.

Pada PLC, untuk menghubungkan dengan peralatan lainnya diperlukan pengalamatan yang tepat. Pola pengalamatan untuk input, output dan blok-blok internal memiliki perbedaan berdasarkan jenis PLC. PLC yang digunakan pada otomatisasi penyiraman bibit ini adalah Siemens, pola pengalamatan yang digunakan adalah sebagai berikut :

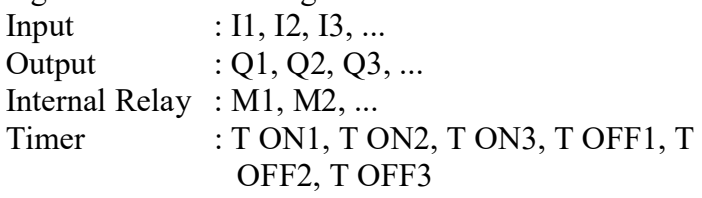

Pada PLC Siemens bahasa pemrograman yang digunakan adalah FBD (Function Block Diagram).FBD merupakan bahasa pemrograman yang berupa blok-blok gerbang logika untuk menggambarkan rangkaian yang di buat.

\section{Sensor}

Sensor adalah alat yang digunakan untuk mendeteksi dan sering berfungsi untuk mengukur magnitude sesuatu.Dengan menggunakan sensor kita dapat mengubah mekanis, magnetis, panas, cahaya dan kimia menjadi tegangan dan arus listrik.Sensor yang digunakan pada otomatisasi penyiraman bibit ini adalah sensor kelembaban tanah.

\section{Relay}

Relay merupakan salah satu perangkat elektronik yang sering digunakan dalam membuat suatu perangkat keras. Relay bekerja bedasarkan arus yang melewati kumparan yang melilit pada batang magnet. Apabila ada arus yang cukup melewati kumparan maka akan terjadi induksi pada batang magnet, induksi ini akan mengakibatkan batang magnet menarik armature berporos. Dengan demikian gerakan armature berporos ini dapat dipakai untuk menutup dan membuka kontak.

\section{Permasalahan}

Pada budidaya tanaman, ketersedian air sangatlah penting.Bibit tanaman tidak bisa hidup dan berkembang dengan baik jika air pada tanah tidak sesuai dengan kebutuhan.Untuk itu perlu dilakukan penyiraman bibit secara teratur dan terjadwal. Ketersediaan air pada masa pembibitan taaman harus benar-benar diperhatikan, jika kekurangan air bibit akan kering dan akhirnya mati. Sebaliknya jika kelebihan air, bibit akan busuk. Dengan selalu terpenuhinya kebutuhan akan air, maka tanaman dapat tumbuh, berbuah dan berkembang biak dengan baik.
Lain halnya dengan tanaman dewasa yang sudah tumbuh, ia telah memiliki akar yang banyak dan kuat sehingga mampu mencari air dengan sendirinya, jarang disirampun biasanya dapat bertahan hidup. Saat ini penyiraman bibit masih dilakukan oleh tenaga manusia sehingga memerlukan tenaga dan waktu yang lama.

\section{Literatur Review}

1. Tanaman memerlukan air untuk dapat tumbuh secara optimal. Untuk itulah kondisi kelembaban tanah harus dijaga pada suatu keadaan tertentu yang sesuai dengan kebutuhan tanaman. Di sisi lain, keterbatasan indera manusia menyebabkan kondisi kadar air tanah tidak dapat diketahui secara tepat. Oleh karena itu, diperlukan suatu sistem yang bekerja secara otomatis dan cerdas untuk melakukan penyiraman tanaman (Ridwan).

2. LOGO!soft comport user documentation ,cara pemakaian software LOGO!soft sebagai sofware penulisan program yang akan di upload ke PLC. Dalam dokumen tersebut kita dijelaskan tata cara penulisan program dan contoh - contoh programnya (Anonim, 1999).

3. Introduction to PLC Controllers, pengenalan sistem control yang ada pada PLC Siemens tipe 230 RC lengkap dengan input dan outputnya serta kekurangan dan kelebihan dari PLC Siemens tipe $230 \mathrm{RC}$ (Anonim).

4. Istilah sistem kendali dalam teknik listrik mempunyai arti sesuatu peralatan atau sekelompok peralatan yang digunakan untuk mengatur fungsi kerja suatu mesin dan memetakan tingkah laku mesin tersebut sesuai dengan yang di kehendaki. Fungsi kerja mesin tersebutmencakup antara lain menjalankan (start), mengatur (regulasi), dan menghentikan suatu proses kerja. Pada umumnya, sistem sistem kendali merupakan suatu kumpulan peralatan lain yang menjamin stabilitas dan transisi halus serta ketepatan suatu proses kerja (Budiyanto dan Wijaya, 2003).

5. Sistem kontrol proses terdiri atas sekumpulan piranti-piranti dan peralatan-peralatan elektronik yang mampu menangani kestabilan, akurasi, dan mengeliminasi transisi status yang berbahaya dalam proses produksi. Masing-masing komponen dalam sistem kontrol proses tersebut memegang peranan pentingnya masing-masing, tidak peduli ukurannya. Misalnya saja, jika sensor tidak ada atau rusak atau tidak bekerja, maka sistem kontrol proses tidak akan tahu apa yang terjadi dalam proses yang sedang berjalan (Putra).

6. Penyiraman Tanaman Dengan Roda Penggerak Berbasis Mikrokontroler AT89S51, Alat ini berfokus pada kemampuan alat untuk mendeteksi air yang tergenang hingga pada ketinggian tertentu, dimana terdapat empat buah sensor sederhana guna mendeteksinya. empat buah 
sensor inilah yang kemudian menjadi input yang dibaca mikrokontroler AT89S51 yang akan menentukan pergerakan motor DC pada alat. Alat akan berjalan apabila ke empat buah sensor mendapat kondisi basah dan akan berhenti bila mendapat kondisi kering (Sigit, 2009).

7. Sistem Otomasi Penyiraman Tanaman Pada Rumah Kaca Berbasis Mikrokontroler MCS-51. Telah dilakukan perancangan dan perealisasian sistem penyiraman tanaman pada rumah kacaberbasis mikrokontroler AT89S51. Hasil yang diperoleh berupa nilai hambatan pada tanah yang berbeda-beda jenisnya dengan fungsi sebagai setting point di dalam mengatur dan mengukur tingkat resistansipada tanah serta untuk mengetahui tingkat kebutuhan air pada tanah (Nugroho dan Priharnantho, 2008).

\section{Metodologi}

Dalam perancangan program sistem otomasi penyiraman bibit tanaman ini menggunakan alat dan bahan sebagai berikut:

1. PLC Siemens tipe $230 \mathrm{RC}$

2. Bor listrik

3. Tang potong dan obeng

4. Solder dan penyedot timah

5. Multimeter

6. Dioda $1 \mathrm{~N} 1002$

7. Relay $12 \mathrm{~V}$

8. Transistor BC 108

9. Resistor $2 \mathrm{~K} 2 \mathrm{Ohm}$

10. Variable Resistor $1 \mathrm{M} \mathrm{Ohm}$

11. Trafo 1 Ampere

12. Plat tembaga

\section{Cara Kerja Sistem Otomasi Penyiraman Bibit Tanaman \\ Cara Kerja Sensor Kelembaban}

Transistor difungsikan sebagai saklar dimana TR1 akan dikendalikan (diaktifkan) melalui basis, ketika tegangan dikaki basis melampaui tegangan saturasi maka TR1 akan aktif dan arus akan mengalir dari kaki C ke kaki E. Tegangan di kaki basis TR1 didapat dari rangkaian pembagi tegangan antara VR1 dan sensor (elektroda).

Sensor (elektroda) akan membaca nilai resistansi tanah yang di ukur. Ketika kelembaban tanah tinggi (basah) maka nilai resistansi tanah akan turun (rendah) dan ketika kondisi tanah kering maka nilai resistensinya tinggi. Perubahan nilai resistensi dari tanah ini yang dimanfaatkan untuk merubah tegangan di kaki basis pada TR1.Sedangkan VR1 difungsikan untuk kalibrasi (penentu titik kelembapan yang di inginkan). Ketika kondisi tanah basah, maka perbandingan resistensi sensor lebih kecil dari resistensi VR1 sehingga tegangan di kaki basis di bawah nilai tegangan saturasi sehingga TR1 akan OFF. Ketika kondisi tanah kering maka perbandingan resistensi sensor lebih besar dari pada resistensi VR1, sehingga tegangan pada kaki basis melebihi tegangan saturasi sehingga TR1 pada kondisi ON sehingga arus akan mengalir dari kaki colector ke kaki basis.

Ketika TR1 aktif (on) maka tegangan pada basis TR2 akan melebihi tegangan saturasi dan TR2 akan hidup. Ketika TR2 hidup maka arus akan mengalir dari kaki collector ke kali emitor TR2 yang melebihi kaki-kaki relay. Karena relay dialiri arus maka relay akan on dan hal ini akan menswitch relay pada kondisi NC. Kondisi relay ini digunakan untuk menghidupkan (memberi inputan) pada PLC.

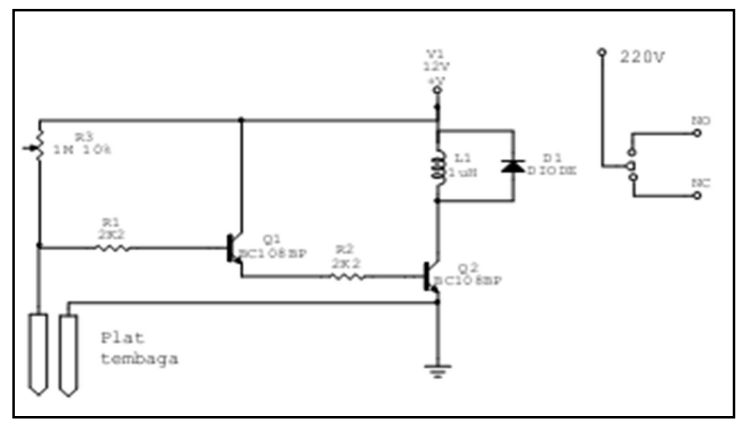

Gambar 1.Rangkaian Sensor Kelembaban Cara Kerja PLC

PLC bekerja berdasarkan input / masukan dari sensor dan program yang telah dibuat. Sensor akan memberikan masukan berupa arus yang dihubungkan ke input Keluaran dari PLC (Q1) akan dihubungkan ke relay untuk menghidupkan atau mematikan pompa air. Keluaran dari PLC (Q1) akan dihasilkan program PLC berdasarkan masukan / input dari I1 dan masukan dalam program.

\section{Cara Kerja Relay}

Relay bekerja berdasarkan masukan yang diperoleh dari keluaran PLC. Jika keluaran dari PLC (Q1) berupa kondisi logika 1, maka arus listrik akan mengalir ke lilitan kumparan pada batang magnet yang ada di relay. Hal ini akan menyebabkan induksi dan menggerakkan poros sehingga terjadi kontak (saklar dalam kondisi on).

\section{Perancangan Perangkat Keras}

PLC menjadi pusat pengendalian sistem. PLC bekerja setelah menerima masukan dari sensor, kemudian akan memberikan instruksi berupa masukan dalam bentuk pewaktuan yang telah di program sebelumnya. Output dari PLC akanmengaktifkan relay. Jika relay

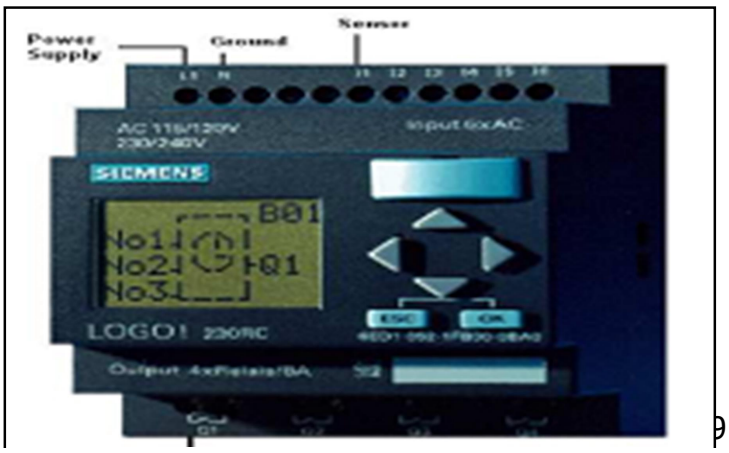


dalam kondisi aktif, maka mesin pompa air akan bekerja untuk melakukan penyiraman. PLC akan bekerja selama PLC masih menerima arus listrik.

\section{Perancangan Perangkat Lunak}

Setelah mengetahui cara kerja dari semua alat dan perancangan perangkat keras, maka langkah selanjutnya yaitu merancang perangkat lunak .Bahasa yang digunakan untuk pembuatan program adalah Function Block Diagram (FBD).

Sensor yang akan digunakan sebagai salah satu masukan dihubungkan dengan input sedangkan pengaturan waktu untuk menentukan kapan proses penyiraman akan dilakukan diprogram menggunakan clock timer yang ada di special function (SF).Untuk keluaran dari PLC dapat menggunakan Q1 yang akan dihubungkan dengan peralatan eksternal, dalam hal ini relay. Jika kondisi tanah kering / kurang basah, maka I1 akan mendapat masukan logika 0. B02 adalah blok program yang berisi program timer yang digunakan untuk mengatur pewaktuan. Pewaktuan ini akan mengatur agar output dari B02 bernilai logika 1 atau logika 0. B02 akan bernilai logika 1 pada jam 05:50 dan akan bernilai logika 0 dimulai pada jam 06:00. Pada jam 16:50 output B02 akan bernilai logika 1 sampai dengan jam 17:00, kemudian output B02 akan bernilai 0 .

Keluaran dari PLC (Q1) akan bernilai 1, apabila I1 mendapat masukan logika 1 dan output dari B02 bernilai 1. Jika salah satu dari I1 atau B02 bernilai logika 0, maka ouput dari Q1 adalah 0 .

\section{Implementasi}

Langkah yang dilakukan selanjutnya adalah cara penginstalasian pengawatan pada PLC. Langkahlangkah pemasangan pada PLC adalah sebagai berikut:

1. Pengawatan L (api) arus yang dihubungkan pada power supply pada PLC.

2. Pengawatan pada $\mathrm{N}$ sebagai ground/netral

3. Pengawatan pada masukan PLC (I1 dihubungkan dengan sensor kelembaban tanah).

4. Pengawatan pada keluaran PLC (Q1 dihubungkan dengan pompa air / jet pump).

\section{Hasil dan Pembahasan}

Berikut ini adalah tabel hasil dari pengujian:

Tabel 1. Tabel hasil pengujian penyiraman

\begin{tabular}{|c|c|c|}
\hline $\begin{array}{l}\text { Port input (i) } \\
\text { / output (q) }\end{array}$ & Hasil & Keterangan \\
\hline $\begin{array}{l}\text { I1 sebagai } \\
\text { sensor ON / } \\
\text { OFF yang } \\
\text { terhubung } \\
\text { pada power } \\
\text { supplay }\end{array}$ & $\begin{array}{l}\text { Dapat bekerja } \\
\text { memberikan } \\
\text { masukan ke } \\
\text { PLC }\end{array}$ & Benar \\
\hline $\begin{array}{l}\text { Pada kondisi } \\
\text { tanah basah }\end{array}$ & $\begin{array}{l}\text { Sensor } \\
\text { bekerja } \\
\text { memberikan } \\
\text { masukan } 1 \\
(\mathrm{ON}) \text { ke PLC }\end{array}$ & Benar \\
\hline $\begin{array}{l}\text { Pada kondisi } \\
\text { tanah kering } \\
\text { Gambar 3. Pengav }\end{array}$ & $\begin{array}{l}\text { Sensor } \\
\text { bekerja } \\
\text { memberikan } \\
\text { masukan 0 } \\
\text { tan pada PLC }\end{array}$ & Benar \\
\hline & PLC & \\
\hline $\begin{array}{l}\text { Program timer: } \\
\text { Mo - Su } \\
\text { On : } 05: 55 \\
\text { Off : } 06: 00\end{array}$ & $\begin{array}{l}\text { Dapat bekeja } \\
\text { sesuai dengan } \\
\text { waktu yang } \\
\text { diberikan ( } 5 \\
\text { detik) }\end{array}$ & Benar \\
\hline $\begin{array}{l}\text { Program timer: } \\
\text { Mo - Su } \\
\text { On : } 16: 55 \\
\text { Off }: 17: 00\end{array}$ & $\begin{array}{l}\text { Dapat bekeja } \\
\text { sesuai dengan } \\
\text { waktu yang } \\
\text { diberikan ( } 5 \\
\text { detik) }\end{array}$ & Benar \\
\hline $\begin{array}{l}\text { Q1 sebagai } \\
\text { keluaran }\end{array}$ & $\begin{array}{l}\text { Dapat bekeja } \\
\text { sesuai dengan } \\
\text { masukan dari } \\
\text { sensor dan } \\
\text { pewaktuan } \\
\text { (timer) }\end{array}$ & Benar \\
\hline
\end{tabular}

1. Sensor akan memberikan masukan pada PLC, melalui I1.

2. Sensor akan bekerja sesuai dengan kondisi tanah. Pada saat tanah kering, sensor akan memberikan masukan 0 (off) dan pada kondisi tanah basah, sensor akan memberikan masukan 1 (on).

3. Jika I1 (sensor) pada posisi ON dan pewaktuan pada posisi jam 05:55, maka Q1 (keluaran) yang terhubung dengan jet pump akan bekerja, sehingga jet pump akan bekerja untuk melakukan penyiraman. Pada posisi jam 06:00, Q1 akan berhenti bekerja (off), sehingga jet pump akan berhenti melakukan penyiraman.

4. Jika I1 (sensor) pada posisi ON dan pewaktuan pada posisi jam 16:55, maka Q1 (keluaran) yang terhubung dengan jet pump akan bekerja, sehingga jet pump akan bekerja untuk melakukan penyiraman. Pada posisi jam 17:00, Q1 akan berhenti bekerja (off), sehingga jet pump akan berhenti melakukan penyiraman.

5. Jika I1 (sensor) pada posisi off, maka Q1 akan pada posisi off, walaupun pada posisi jam 05:55 dan 16:55. 
UNISTEK, 2018, Edisi 5, No.1

6. Jika PLC dalam keadaan aktif (mendapat masukan arus listrik), maka proses diatas akan dilakukan secara berulang-ulang.

\section{Kesimpulan}

Dari hasil penelitian dapat diambil kesimpulan sebagai berikut:

1. Pengendalian proses kerja pada proses penyiraman bibit tanaman dilakukan dengan cara mengatur pewaktuan (timer) yang dapat disesuaikan dengan kebutuhan bibit tanaman.

2. Sensor kelembaban tanah akan memberikan masukan pada PLC dan bersama-sama dengan pewaktuan (timer) untuk mengatur keluaran (Q1).

3. Dengan menggunakan PLC proses penyiraman lebih mudah karena proses penyiraman bibit tanaman dapat dilakukan secara otomatis, sesuai program yang sudah dibuat di PLC dan akan bekerja selama arus listrik masih mengalir.

4. Program dapat diubah dengan mudah, menyesuaikan dengan jenis bibit tanaman yang akan disiram

\section{Daftar Pustaka}

Anonim, Introduction to PLC Controllers, http://www.mikroe.com/en/books/plcbook/plcb ook.htm

Anonim. (1999). LOGO!soft comport user documentation, Siemens AG.

Budiyanto. M. \&Wijaya, A. (2003).Pengenalan Dasar dasar PLC. Jogjakarta: Gaya Media.

Nugroho, A. \&Prihanantho.(2008). Sistem Otomasi Penyiraman Tanaman Pada Rumah Kaca Berbasis Mikrokontroler MCS-51. Jakarta

Putra, A.E.PLC : Konsep, Pemrograman dan Aplikasi, kelas-mikrokontroler.com

Ridwan, W.Sistem Penyiraman Tanaman Otomatis Berbasis Logika Fuzzy, Universitas Negeri Gorontalo.

Sigit, S. (2009). Penyiraman Tanaman Dengan Roda Penggerak Berbasis Mikrokontroler AT89S.Jakarta: Universitas Gunadarma, 
Jurnal Keilmuan dan Aplikasi Teknik

UNISTEK, 2018, Edisi 5, No.1 